\title{
POLITICS IN THE NEW
}

HARD TIMES 
A volume in the series

Cornell Studies in Political Economy

Edited by Peter J. Katzenstein

A list of titles in this series is available at www.cornellpress.cornell.edu. 

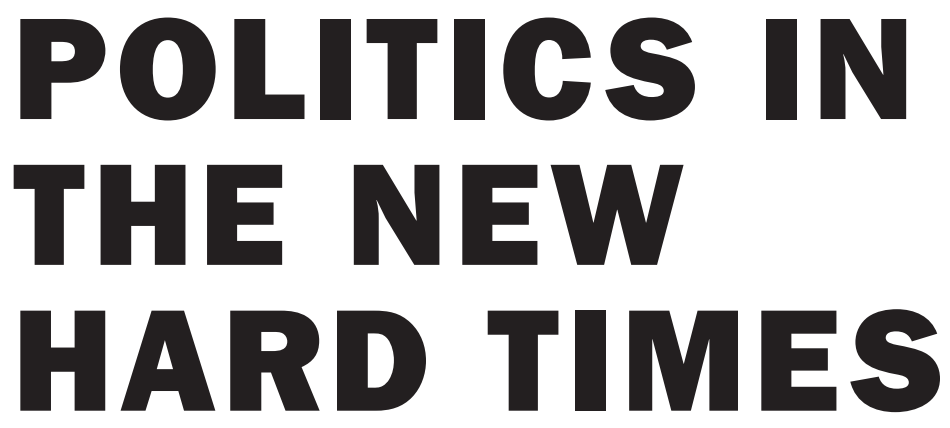

The Great Recession in

Comparative Perspective

\section{Edited by Miles Kahler and David A. Lake}




\section{Copyright (c) 2013 by Cornell University}

All rights reserved. Except for brief quotations in a review, this book, or parts thereof, must not be reproduced in any form without permission in writing from the publisher. For information, address Cornell University Press, Sage House, 512 East State Street, Ithaca, New York 14850.

First published 2013 by Cornell University Press

First printing, Cornell Paperbacks, 2013

Printed in the United States of America

\section{Library of Congress Cataloging-in-Publication Data}

Politics in the new hard times : the great recession in comparative perspective / edited by Miles Kahler and David A. Lake.

p. cm. - (Cornell studies in political economy)

Includes bibliographical references and index.

ISBN 978-0-8014-5151-5 (cloth : alk. paper)

ISBN 978-0-8014-7827-7 (pbk. : alk. paper)

1. Global Financial Crisis, 2008-2009-Political aspects. 2. World politics2005-2015. 3. International economic relations-Political aspects. I. Kahler, Miles, 1949- II. Lake, David A., 1956- III. Series: Cornell studies in political economy.

HB37172008 .P65 2013

$$
330.9^{\prime} 0511-\mathrm{dc} 23 \quad 2012033983
$$

Cornell University Press strives to use environmentally responsible suppliers and materials to the fullest extent possible in the publishing of its books. Such materials include vegetable-based, low-VOC inks and acid-free papers that are recycled, totally chlorine-free, or partly composed of nonwood fibers. For further information, visit our website at www.cornellpress.cornell.edu.

Cloth printing Paperback printing $\begin{array}{llllllllll}10 & 9 & 8 & 7 & 6 & 5 & 4 & 3 & 2 & 1\end{array}$

$\begin{array}{llllllllll}10 & 9 & 8 & 7 & 6 & 5 & 4 & 3 & 2 & 1\end{array}$ 
To Peter Gourevitch

Scholar, Colleague, Friend 
